\title{
Road to a Great Monetary Power
}

\author{
China's Changing Role \\ in the International \\ Monetary System
}

Li Wei and Su Han

\begin{abstract}
Since the beginning of its reform and opening up over three decades ago, China has taken great efforts to integrate into the GATT/ WTO-centered international trade system and the U.S. Dollar-centered international monetary system. By using the U.S. Dollar as the principal currency in its international economic engagement while exercising strict capital controls domestically, China has practically adopted a U.S. Dollardependent strategy to promote export, attract foreign investment, and maintain financial security, thus it has achieved lasting economic growth. However, with the declining credibility of the U.S. Dollar due to the U.S. financial crisis in 2008, and the increasing strategic competition between China and the United States, more and more Chinese in the policy and academic circles are skeptical of China's highly dependent monetary policy. Since 2009, China has begun to adopt a more proactive international monetary strategy by taking such measures as promoting the internationalization of the RMB, initiating new reforms of the international
\end{abstract}

Li Wei is Associate Professor at the School of International Studies, Renmin University of China. Su Han is an MA candidate at the School of International Studies, Renmin University of China.

(c) 2015 World Century Publishing Corporation and Shanghai Institutes for International Studies China Quarterly of International Strategic Studies, Vol. 1, No. 2, 265-282

DOI: $10.1142 / S 237774001550013 X$ 
monetary system, and fostering a new regional monetary order. Such changes imply that China is changing its role: moving from being a dependent to a reformer of the U.S. Dollar system, which reflects a salient dimension of the evolving relationships between China and the broader international system.

Keywords: International monetary system; the U.S. Dollar system; RMB internationalization; reformer.

Since the beginning of China's reform and opening up in 1978, its foreign economic policy has had two basic goals: firstly to gain access to the open consumer market of the West by employing an export-oriented trade policy, culminating in China's entry into the WTO in 2001; secondly to enhance China's manufacturing industry by importing advanced technologies and managerial expertise especially through attracting foreign direct investment (FDI). Both depend on a relatively stable international currency as a medium between domestic and global markets. Thus China adopted an international monetary policy largely dependent on the U.S. Dollar, confining the renminbi (RMB), the Chinese currency, to domestic markets, while using the U.S. Dollar as the main currency in its international economic engagement. To a large extent, it was a "free-riding policy" on the U.S. Dollar.

This policy has been imperative in China's rapid economic rise over the past decades, as it not only facilitated China's export and procurement of FDI, but helped fend off financial and monetary risks as well. After the outbreak of the U.S. financial crisis in 2008, however, both political and economic elites in China have come to realize the growing price that China may need to pay for free-riding, and thus they have sought to lessen China's dependence on the U.S. Dollar system by adjusting the domestic monetary policy and engaging in ever more active monetary diplomacy. With such efforts, China is increasingly becoming a reformer of the international monetary system.

This article first analyzes China's changing role in the international monetary system as well as its causes, and then discusses China's further endeavors in reforming the current system into a more just and sustainable one. 


\section{Free-Riding on the U.S. Dollar System}

As a soft mien of U.S. hegemony, the U.S. Dollar-centered international monetary system (the Bretton Woods system), together with U.S. military supremacy and the U.S.-led international economic institutions including the International Monetary Fund (IMF), the World Bank, and General Agreement on Tariffs and Trade (GATT), were keys to the stabilization of the post-World War II financial order and the rapid economic recovery of the capitalist world. ${ }^{1}$ Even after the collapse of the Bretton Woods system in 1973 caused by a chain of major U.S. Dollar crises in the preceding years, the U.S. Dollar maintained its central role in the international monetary

For three decades

after opening up,

China maintained its dependence on the U.S. Dollar for financial security and easier access to the world market.

\section{system.}

To promptly connect itself with the enticing Western markets for trade opportunities, investment, and new technologies, China chose to join the U.S. Dollar system shortly after it began its reform and openingup process in the late 1970s. By using the U.S. Dollar as the principal currency in its international economic engagement, China adopted a "U.S. Dollar-dependent strategy" and refrained from attempts to internationalize the RMB or to create an independent regional monetary alliance like Europeans did, thus enjoying the many dividends of free-riding on the U.S. Dollar system. To be more specific, China's dependent strategy on the U.S. Dollar consisted of three key elements.

First, China adopted the U.S. Dollar as a principal currency not only for pricing and settlement in its foreign trade, FDI, and other international financial activities, but also in GDP accounting, since its national economic accounting system was established in 1985. For example, the U.S. Dollar had been used in the settlement of up to 90 percent of China's foreign trade before 2008, and remains a principal currency for settlement despite its declining credibility due to the U.S. financial crisis. In comparison, only 22 percent of

${ }^{1}$ Charles P. Kindleberger, “International Public Goods without International Government," American Economic Review, Vol. 76, No. 1 (March 1986), pp. 1-13. 
China's total trade debts were settled with the RMB as late as $2014 .^{2}$ Such high dependence on the U.S. Dollar, together with its rapidly expanding surplus in foreign trade, is the key contributor to China's ever-growing U.S. Dollar reserves.

Second, China closely pegged the value of the RMB to the U.S. Dollar, virtually taking it as the sole referent currency for the RMB's exchange rate. This policy has largely continued even after China began to adopt floating exchange rates of the RMB in 1994. For instance, the benchmark exchange rate of the RMB to the U.S. Dollar was kept at 8.2-8.3 to 1 between 1995 and $2005 .{ }^{3}$ Not totally by chance, these ten years witnessed the foundation of China's export-oriented economy. Although China revised its U.S. Dollar-pegged policy and began to adjust the RMB exchange rate to a basket of referent currencies on July 21, 2005, ${ }^{4}$ the U.S. Dollar remained the most important currency in the basket. After the U.S. financial crisis broke out in 2008, China once again pegged the RMB to the U.S. Dollar for financial stability, and resumed limited floating exchange rates only after June 2010.

Third, China kept enlarging U.S. Dollar assets as its major foreign exchange reserve assets. Under the official guideline to prioritize U.S. Dollar assets, China's foreign exchange reserves have topped the world with an increase of 369.7 percent over the past decade. According to the People's Bank of China, U.S. Dollar assets accounted for nearly 70 percent of China's total foreign exchange reserves in 2014, followed by the EURO and British Pound assets (about 20 percent) and the Japanese Yen assets (about 10 percent), while gold assets only constituted 1.05 percent. ${ }^{5}$ Today, of China's total 4-trillion-U.S. Dollar-worth foreign exchange reserves, nearly 3 trillion are U.S. Dollar assets such as the U.S. national debts, federal bonds, and corporate bonds. In reality, China has grown to be the largest holder of

2“Half of China's total trade to be settled in yuan by 2020," Reuters, March 26, 2015, http://uk.reuters.com/article/2015/03/26/uk-china-yuan-offshore-idUKKBNOMM0EL20150326.

${ }^{3}$ Calculation by the authors based on statistics of the People's Bank of China, http:// www.pbc.gov.cn/.

${ }^{4}$ The People's Bank of China Announcement No. 16 (2005): “Announcement of the People's Bank of China on Reforming the RMB Exchange Rate Regime," July 21, 2005.

${ }^{5}$ The People's Bank of China, http://www.pbc.gov.cn/publish/html/kuangjia.htm? $\mathrm{id}=2014 \mathrm{~s} 09 . \mathrm{htm}$. 
the U.S. national debts with 32.4 percent of its foreign exchange reserves invested in them, making China the biggest "stakeholder" in maintaining the stability of the U.S. Dollar. ${ }^{6}$

China's U.S. Dollar-dependent strategy played a key role not only in its integration into the U.S.-centered international economic system, but in enhancing its financial security as well. Thanks to its U.S.-Dollar-pegged policy and tight capital controls, China's domestic financial system remained intact during the Asian financial crisis in 1997. Concerned with its own economic interests and financial security, China also worked closely with the United States at the peak of the U.S. financial crisis, so as to stabilize the value of the Dollar and restore the global financial order. Clearly, China has enjoyed many "free-riding dividends" of the U.S. Dollar - a "double-edged sword" as it is - as international public goods, and thus managed to maintain its economic growth over the past decades.

\section{China as a "Reformer"}

Nevertheless, a new era of post-Cold War international relations, especially economic relations, was dawning, with the outbreak of the U.S. financial crisis in 2008 as well as the European debt crisis and China replacing Japan as the world's second largest economy in 2010. Since then, China has been increasingly doubtful of the U.S. Dollar system, and has contributed to the reformation of the international monetary system with ever more ideas and initiatives. To an increasing degree, China is playing a reformer's role in the international monetary system, which can be seen on all levels.

On the global level, China is strongly advocating the reformation of the system. A salient example is its support for the Group of 20 (G20) to replace the G7 as the basic platform for global economic governance, including monetary management. As a major member of the G20, China has

${ }^{6}$ According to the U.S. Treasury, China held 1,244.3 billion U.S. dollars worth of U.S. national debt in December 2014, accounting for 20.46 percent of the total of 6,153.7 billion, closely followed by Japan. See statistics of the U.S. Treasury, http://www.treasury.gov/resource-center/data-chart-center/tic/Documents/mfh.txt. 
been increasingly active in financial diplomacy to promote a structural reform of the international monetary system, thereby winning it a bigger say in the system. ${ }^{7}$ Over the years, China has been calling for a bigger role of the Special Drawing Right (SDR) to palliate the overdependence of global reserve assets on the U.S. Dollar. As Mr. Zhou Xiaochuan, Governor of the People's Bank of China, proposed before the G20 London Summit in 2009, "The ideal goal of reforming the international monetary system is to create an international reserve currency [such as the SDR] that is delinked from sovereign states, and whose value can be kept stable in the long run, so as to circumvent the intrinsic drawbacks of using sovereign credit currencies as reserve currencies." ${ }^{8}$ This proposal was widely considered as China's first open challenge to the U.S. Dollar's predominance. ${ }^{9}$ Besides, China is also trying to add the RMB into the basket of base currencies of the SDR. If accepted by the IMF after the organization's review of the SDR in November 2015, the RMB will become a major international currency, and the world's demand for it is likely to explode, which will mark a huge boost to the RMB's international status.

At the same time, China is also very active in reforming the existing international financial institutions to enhance its say and share in them. By increasing its capital in the IMF and the World Bank, China's quota in the IMF rose from 3.994 percent before 2008 to 6.390 percent in 2010, and its voting share rose from 3.803 percent to 6.068 percent accordingly. ${ }^{10}$ China's voting share in the International Bank for Reconstruction and Development (IBRD), the key decision-making body of the World Bank,

${ }^{7}$ Cui Zhinan and Xing Yue, "From G7 Era to G20: The Transition of International Financial Governance Regime," World Economics and Politics, No. 1 (January 2011), pp. 134-154.

${ }^{8}$ Zhou Xiaochuan, “Guanyu Gaige Guojihuobitixi de Sikao [Reflections on Reforming the International Monetary System]," PBC Website, March 23, 2009, http://www.pbc.gov.cn/ publish/hanglingdao/36/2010/20100914193900497315048/20100914193900497315048_html.

${ }^{9}$ Daniel W. Drezner, “Bad Debts: Assessing China's Financial Influence in Great Power Politics," International Security, Vol. 34, No. 2 (Fall 2009), p. 39.

${ }^{10}$ IMF Finance Department: "Quota and Voting Shares before and after Implementation of Reforms Agreed in 2008 and 2010," March 3, 2011. http://www.imf.org/external/np/sec/ pr/2011/pdfs/quota_tbl.pdf. 
also rose to 5.25 percent in $2015 .{ }^{11}$ It is expected that China will surpass Germany, France, and the UK as the third largest shareholder of the IMF and the World Bank when the reform is completed, ${ }^{12}$ though the blueprint of the reform is still stuck at the U.S. Senate at present. To demonstrate China's firm stance, Chinese President Xi Jinping reiterated the urgency of the IMF quota reform at the 9th G20 Summit held in Brisbane in November 2014. Furthermore, in the personnel reform of major international financial institutions, Mr. Zhu Min, former Deputy Governor of the People's Bank of China, was named Special Adviser to the IMF President in May 2010 and elected as IMF Vice President in July 2011, only three years after Mr. Justin Yifu Lin, a renowned Chinese economist, became Vice President of the World Bank. With more and more Chinese faces assuming key posts of global institutions, China will inevitably have more say in the management of world financial affairs and make bigger contributions as a responsible great power. ${ }^{13}$

China is growing to be a reformer of the international monetary system on all fronts.
On the regional level, China is taking new initiatives in promoting regional monetary cooperation in such institutions as the BRICS, the "ASEAN-plus-Three (China, Japan, and South Korea)," and the Shanghai Cooperation Organization (SCO), in order to lower the whole region's dependence on the U.S. Dollar system. Especially since the outbreak of the U.S. financial crisis, not only has China played a leading role in advocating bigger say and share for regional members in international financial institutions, it has also managed to enhance cooperation with other members in settling trade with local currencies, setting up the BRICS Contingency Reserve Mechanism, and founding

${ }^{11}$ Corporate Secretariat of World Bank: "International Bank for Reconstruction and Development Voting Power of Executive Directors," http://siteresources.worldbank.org/ BODINT/Resources/278027-1215524804501/IBRDEDsVotingTable.pdf.

12“IMF Tongguo Fen'e Gaigefang'an, Zhongguo Paiming cong Binglie Diliu Yueju Disan [IMF Passes Quota Reform Plan. China Jumps to the Third Place from the Sixth]," China News, November 6, 2010, http://www.chinanews.com/cj/2010/11-06/2638998.shtml.

${ }^{13}$ Li Wei, “The Rise of China's Financial Diplomacy," World Economics and Politics, No. 2 (March 2013), pp. 77-98. 
the BRICS Development Bank, so as to foster a more balanced international monetary system and reduce the U.S. Dollar monopoly. For example, the opening of the East Asian Foreign Exchange Reserves established by the ASEAN-plus-Three on March 24, 2010, marked the beginning of a financial crisis management and prevention mechanism that covers the whole region, with Mr. Wei Benhua, former Deputy Director of China's State Administration of Foreign Exchange, as its first director. Primarily because of China's contribution, the East Asian Foreign Exchange Reserves doubled its size to 240 billion U.S. dollars in 2012, and the proportion of its terms for loans parallel to the IMF's dropped to 70 percent, a big step toward its full self-determination. ${ }^{14}$ As the basis of RMB internationalization, China is also promoting the regionalization of the RMB by working with other SCO members to foster a regional settlement and payment system for trade and investment, to encourage settlement with local currencies, and to set up an SCO development bank.

Most strikingly, the Asian Infrastructure Investment Bank (AIIB) initiative was formally launched in Beijing in October 2014, a year after President Xi Jinping's proposal on his visit to Indonesia. By April 15, 2015, a total of 57 countries had confirmed their participation as founding members - 20 of them are outside Asia, and some are U.S. allies or strategic partners. Expected to be fully established by the end of 2015, the China-led AIIB is regarded by many as a rival of the existing international financial institutions like the IMF, the World Bank, and the Asian Development Bank (ADB) ${ }^{15}$ which are considered as being dominated by developed countries like the United States and Japan. The rapid progress of the initiative showcases China's growing mobilizing power in international financial and monetary arenas.

On the bilateral level, China continues to enhance the RMB's international status through active monetary diplomacy. Starting from settling

14“Dongya Waihui Chubeiku Zhubu Tuogou IMF, Guimo Jiang Kuorong Yibei [East Asian Foreign Exchange Reserves to Be Delinked from IMF with Doubled Size], Ifeng Finance, March 22, 2012, http://finance.ifeng.com/news/hqcj/20120322/5785163.shtml.

${ }^{15}$ Tania Branigan, "Support for China-led Development Bank Grows despite US Opposition," The Guardian, March 14, 2015, http://www.theguardian.com/world/2015/mar/13/ support-china-led-development-bank-grows-despite-us-opposition-australia-uk-new-zealand-asia. 
certain cross-border trade with the RMB after the outbreak of the U.S. financial crisis, China has taken substantial measures to lower its dependence on the U.S. Dollar and to expand its own monetary partnership networks. "Currency-swap diplomacy" is the first step toward the RMB internationalization. Since the first currency swap deal was made between China and South Korea in late 2008, China has signed currency reciprocal agreements with 28 countries and regional governmental institutions, with the size of agreements with South Korea, the European Central Bank (ECB), Singapore, the UK, Australia, and Canada exceeding 200 billion RMB each, making the RMB-centered currency swap network the third largest in the world, only behind the U.S. Dollar-centered and the EURO-centered ones.

On the basis of the ever expanding currency swap networks, China's next step is to encourage settlement of international trade with the RMB. Since 2013, China has been pushing for trade settlement with local currencies under both multilateral and bilateral frameworks, and has reiterated this goal in many joint statements with other governments to augment its effect. Over little more than two years, China has made diplomatic arrangements with about 30 countries including Russia, South Korea, and India on the issue and begun to settle more and more cross-border trade with the RMB, which is now the fifth largest trade-settling currency in the global market. ${ }^{16}$

\section{The RMB is the fifth} largest trade-settling currency and seventh reserve currency in the world.
The growing trade settlement with the RMB boosts greater demands for direct transaction between the RMB and other currencies, the goal toward which China has taken many diplomatic efforts since 2010, especially after 2014. At present, the RMB can trade directly with nine foreign currencies such as the EURO, the British Pound, the Singapore Dollar, and the South Korean Won, apart from the U.S. Dollar. This implies that the exchange rates between the RMB and other currencies are increasingly a function of the

16“Renminbi Yuesheng wei Quanqiu Diwuda Zhifu Huobi [RMB Ranks the Fifth Trade-Settling Currency in the World]," China News, January 28, 2015, http://finance.chinanews.com/fortune/2015/01-28/7013725.shtml. 
quoted prices of transactors, rather than decided mainly by the value of the U.S. Dollar as an intermediary currency.

With the expanding use of the RMB in settlement, payment, and direct transactions, an RMB clearing mechanism is taking shape to facilitate use of the RMB on a larger scale. Since 2013, China has signed memorandums with 11 countries including Singapore, Germany, and the UK on the RMB clearing mechanism, a sign of rapid development of the overseas network for RMB clearing and rising status of the RMB in global markets.

In addition to bilateral monetary diplomacy, China is also promoting the RMB as an international reserve currency. First acknowledged by the Philippines in December 2006 as one of its reserve currencies, the RMB has been recognized as a reserve currency by the central banks of 40 countries and regions such as Malaysia, South Korea, Cambodia, and Thailand, making it the seventh most important reserve currency of the world. ${ }^{17}$

It can be concluded from above that China is adapting its past role of mainly being a free-rider on the U.S. Dollar system to becoming a proactive reformer of the system, in order to better protect its rights and interests, as well as to seek more financial influence on the world stage. This move is considered by many as the biggest challenge to the U.S. Dollar-centered international monetary system.

\section{Motivators of China's Role Change}

Admittedly, the transformation of China's role in the international monetary system is a result of both the weakening of the U.S. Dollar system and China's pursuit of greater power and interests in the system. Understanding such drivers behind China's role change is the basis of grasping the future trajectory of the international monetary system.

The ultimate motivator of China's role change is its growing concern over the insecurity of the U.S. Dollar system, in which the U.S. Dollar can serve as instrumental global public goods when the United States' economic situation remains good, but becomes predacious in times of U.S. economic downswing. Due to the United States' unrestricted use of the political and

17 “RMB Becomes the 7th Global Reserve Currency," People's Daily Online, October 23, 2014, http://finance.people.com.cn/n/2014/1023/c1004-25891863.html. 
economic power generated from the hegemonic status of the Dollar, there has been a serious imbalance in the share of power and interests between the United States and other countries in the international monetary system.

The United States nets huge profits from the global use of the Dollar mainly by two means. First by "seigniorage," the revenue taken from the gap between the face value and actual value of the Dollar. Research indicates that the United States has acquired roughly 2 trillion dollars of seigniorage in total since the end of World War II. ${ }^{18}$ Today, with over 900 billion U.S. dollars in cash, about two-thirds of which circulate abroad, the United States casts seigniorage on at least 600 billion dollars. A variant of seigniorage is "inflation tax," which refers to the financial loss of value suffered by mostly foreign dollar-holders and fixed-rate bond-holders, due to the effects of inflation caused by the United States' over-issuance of the Dollar. As the United States generally pays to Dollar-reserve countries an interest of about 3 percent each year, an inflation rate of 3 percent would automatically write off the interest the United States needs to pay. Over the past decades, the United States has many times adopted such monetary policies as inflation and depreciation of the Dollar to shift its own economic burden onto those creditor countries, ${ }^{19}$ a practice regarded as "revenue of last resort" by political economists. ${ }^{20}$ Indeed, such "power to deflect" is usually the most tempting and harmful privilege of a monetary hegemon $^{21}$ — the many rounds of quantitative easing (QE) launched by the U.S. government after the 2008 financial crisis provide a case in point. $^{22}$

Another way the United States benefits from the global use of the Dollar is that it can keep increasing its international borrowing with its

${ }^{18}$ Zhang Ming, The Global Financial Crisis and China's International Financial Strategy (Beijing: China Financial Publishing House, 2010), p. 265.

${ }^{19}$ Susan Strange, “The Persistent Myth of Lost Hegemony," International Organization, Vol. 41, No. 4 (Autumn 1987), p. 569.

${ }^{20}$ Charles A. E. Goodhart, "The Political Economy of Monetary Union," in Peter B. Kenen, ed., Understanding Interdependence: The Macroeconomics of the Open Economy (Princeton: Princeton University Press, 1995), p. 452.

${ }^{21}$ Benjamin J. Cohen, "The Macrofoundations of Monetary Power," in David Andrews, ed., The International Monetary Power (Ithaca: Cornell University Press, 2006), pp. 46-49.

${ }^{22} \mathrm{Li}$ Wei, "Maintenance of Hegemony: International Economic Strategy of the Obama Administration," Foreign Affairs Review, No. 3 (May/June 2013), pp. 59-60. 
"power to delay." 23 Since the United States became a debtor country in 1971, its debts had amounted to 11.46 trillion dollars by 2009 and have continued rising afterwards. As a Chinese scholar sharply points out, the U.S. economy could remain relatively stable in the past despite the serious imbalance between savings and consumption, in large part because the United States could develop on the savings of other countries in a U.S. Dollar-centered international monetary system. ${ }^{24}$

Moreover, the United States also derives much political privilege from its monetary hegemony. For one thing, it exercises great control over global strategic resources such as crude oil with its pricing power; for another, it has much influence on those countries heavily dependent on the Dollar. ${ }^{25}$ One example of how much influence the United States' monetary policy has is its effects on the global price of crude oil. At the prime of the global financial crisis, the global crude oil price dropped from 147 U.S. dollars per barrel in July 2008 to 33 dollars per barrel in February 2009. Yet with two rounds of QE by the U.S. (starting in November 2008 and November 2010, respectively), the oil price rose back to 110 dollars per barrel in 2011. As it is, the ups and downs of global oil price are basically a function of the United States' monetary policy rather than a reflection of real supply and demand in the global market.

Enjoying all the benefits and privileges of an international currencyissuing country, the United States often fails to take the responsibility of stabilizing the global monetary order. Thus, many countries have begun to call for an overhaul of the international monetary system over the past decade. Especially with the declining credibility of the Dollar since the U.S. financial crisis, there has been increasing discussion on limiting the role of the Dollar in the global financial market, and many international organizations such as the UN, the G20, and the BRICS have encouraged greater use of the RMB as an international currency. Meanwhile, the United States has been urging the RMB to appreciate so as to ease the global trade

${ }^{23}$ Benjamin J. Cohen, "The Macrofoundations of Monetary Power," in David Andrews, ed., The International Monetary Power (Ithaca: Cornell University Press, 2006), pp. 41-46.

${ }^{24} \mathrm{Li}$ Ruogu, Reform of International Monetary System and Internationalization of the Renminbi (Beijing: China Financial Publishing House, 2009), p. 2.

${ }^{25}$ Gong Gang, Against All Odds: The Strategy to Turn RMB into a Hard Currency (Beijing: People's Publishing House, 2013), pp. 55-56. 
imbalance and stimulate the U.S. economy. The RMB exchange rate is under the growing scrutiny of the U.S. Congress, and the successive QE rounds of the United States after 2009 are in part targeted for appreciation of

China's role change is motivated both by concerns of the insecure U.S. Dollar system and by its own growing strategic demand. the RMB.

As one of the biggest foreign exchange reserve holders, China is increasingly concerned about the security risks of falling into the "U.S. Dollar Trap." ${ }^{26}$ Overdependence on the Dollar and Dollar assets not only impairs China's autonomy in its monetary policy, but it will also make China the biggest victim when the United States deflects its own crisis to the world by depreciating the Dollar. ${ }^{27}$ Therefore, it is necessary for China to forsake its past dependence on the U.S. Dollar and strengthen its own monetary policy.

Other than concerns about the insecurity of the U.S. Dollar system, China's role change is also motivated by its growing demand for political power and economic interests on the world stage. As the international status of a country's currency is a mirror of its political power, ${ }^{28}$ a rising China necessarily seeks more monetary power of its own. With an annual growth rate above 7 percent — even at double-digits in many years over the past two decades, China's nominal GDP is likely to surpass that of the United States as early as $2020{ }^{29}$ its share of the world's total commodity trade has also been expanding, ranking first at 12 percent in 2013. Clearly, the RMB's international status no longer matches China's rapidly rising economic status in the world.

${ }^{26}$ Eswar Prasad, “The Dollar Trap," Harvard Business Review, Vol. 91, No. 12 (December 2013), p. 40.

${ }^{27}$ Morris Goldstein and Nicholas Lardy, "China's Role in the Revived Bretton Woods System: A Case of Mistaken Identity," Institute for International Economics Working Paper No. WP05-2, 2005. p. 9.

${ }^{28}$ Philipp Hartmann, Currency Competition and Foreign Exchange Markets: The Dollar, the Yen and Euro (Cambridge, UK: Cambridge University Press, 1998), p. 2.

${ }^{29}$ See EIU Global Competitiveness Report, quoted from Zhang Qunfa, “Dollar Supremacy and RMB Internationalization," Economic Survey, No. 2 (March/April 2008), p. 44. 
It is widely believed that strengthening the RMB as a major international currency will not only bring vast economic interests to China, but also enhance China's global power as well, including the "power of identity," pricing power over global strategic resources, manipulative power in monetary policies around the world, and "anchor-currency power" over dependent countries. ${ }^{30}$ Especially when China and the United States are engaged in ever more intense strategic competition, ${ }^{31}$ China's enormous foreign exchange reserves invested in the United States' financial market have grown to be a "mutual hostage" to both, which is a key constraint of Sino-U.S. competition. As a result, China has put increasing efforts to reform the U.S. Dollar-centered international monetary system in recent years.

\section{Challenging Way Ahead for the Reformer}

With continuing growth of its economic and political influence in the world, China will be more determined to promote reforms of the international monetary system both by the intra-system approach, i.e., strengthening some of the existing institutions, and by the extra-system approach, i.e., enhancing alternative currencies to balance against the U.S. Dollar monopoly.

The intra-system approach refers to gradual reforms of the norms and institutions within the current international monetary system. Other than strengthening the supervision of existing institutions over the issuance of the U.S. Dollar, i.e., the United States' monetary policy, it is both necessary and possible to develop the IMF into a super-national "central bank of the world" with the power to issue a super-sovereign currency. From as early as the Bretton Woods Conference in July 1944, the British economist John Maynard Keynes proposed creating a super-sovereign currency, the "Bancor," for international settlement. In reality, the SDR founded by the IMF in 1969 is an embryonic form of a super-sovereign currency used for reserve

${ }^{30} \mathrm{C}$. Randall Henning, "The Exchange-Rate Weapon and Macroeconomic Conflict," in David Andrews, ed., The International Monetary Power (Ithaca: Cornell University Press, 2006), pp. 117-138.

${ }^{31}$ Li Wei and Zhang Zhexin, "The New-type Sino-U.S. Relations at an Era of Strategic Competition," Quarterly Journal of International Politics, No. 1 (Spring 2015), pp. 25-53. 
assets and accounting. To promote the SDR's role as an international currency, the IMF issued 250 billion U.S. dollars' worth of additional SDR in

China is devoted to RMB internationalization while strengthening certain institutions in the existing international monetary system. 2009, 100 billion of which was shared among developing and rising countries. ${ }^{32}$

Nevertheless, due to such lingering problems of the SDR as its inadequate representation of major currencies, ${ }^{33}$ its limited size for extensive use in the world market, and the unbalanced share between developed and developing countries, many reforms have yet to be taken before an "SDR system" is established: First, the mechanisms of pricing, issuance and distribution of the SDR must be improved to increase the weight of the RMB and the currencies of major developing countries in the SDR basket, and the size of the SDR needs to be expanded for wider adoption as reserve assets. Second, the IMF should encourage the use of the SDR in pricing, settlement, borrowing, accounting and other financial businesses around the world. Third, the IMF itself must be reformed promptly so as to enhance its independence, transparency and decision-making process, as well as to increase the share and say of rising economies.

The extra-system approach requires the enhancement of the role of alternative international currencies to balance against the U.S. Dollar hegemony. Growing diversification of international currencies will greatly reduce the costs of market players in switching among currencies, thus rendering more flexibility and efficiency to global economic and financial activities. ${ }^{34}$ With regard to the changing influence of major currencies in the world over the past decade, the future global monetary system is likely to

32“SDR Zengfa Fang'an Chulu Xinxing Guojia Fende Qianyimeiyuan [SDR Additional Issuance Plan Announced: 100 Billion U.S. Dollars Shared by Rising Countries]," China Stock, July 21, 2009, http://www.cnstock.com/08haiwaigs/2009-07/21/content_4447576.htm.

${ }^{33}$ Currently, four major currencies constitute the whole SDR basket, including the U.S. Dollar (41.9 percent), the EURO (37.4 percent), the British Pound (11.3 percent), and the Japanese Yen (9.4 percent).

${ }^{34}$ Masayuki Tadokoro, "After Dollar?" International Relations of the Asia-Pacific, Vol. 10, No. 3 (September 2010), pp. 425. 
develop from one dominated by the U.S. Dollar into one underpinned by the Dollar, the EURO and the RMB. ${ }^{35}$ Competition among the three currencies will inevitably generate new check-and-balance mechanisms for the international monetary system.

With its ever-expanding economy and trade volume as well as its proactive monetary diplomacy, China has achieved rapid progress in RMB internationalization in the past few years. For instance, its trade volume settled with the RMB reached 4.63 trillion in 2013, or 18 percent of its total trade, compared with the meager 3 percent in $2010 .{ }^{36}$ However, facing the U.S.'s super strength and the long-established U.S. Dollar system, China will have to boldly embrace more major reforms domestically before taking the lead in promoting the systemic reformation on the world stage and making the RMB a genuine global currency.

Above all, China needs to exhibit more political accountability both to the domestic public and to the international community. Accountability is not built on policy statements alone, but is also rooted in credibility of the government, developed from day-to-day practice. Domestically, China must carry through the institutional reforms in all fields including strengthening democracy and open policy processes. In global arenas, it is of equal importance for China to adapt to generally acknowledged international norms and shoulder more global responsibilities, so as to win the respect and trust of other countries, as well as foster an image of a "great yet not hegemonic power."

Next, China should keep on developing its "smart power," the combination of hard and soft power, by providing more global public goods. A self-interested and uncharitable mentality does not fit a great power with

As a strong reformer, China must keep developing its political accountability and smart power, while taking coercive measures wisely.

${ }^{35}$ Barry Eichengreen, "The Renminbi as an International Currency," Econometrics Laboratory UC Berkeley online paper, January 2010, http://emlab.berkeley.edu/ eichengr/ renminbi_international_1-2011.pdf.

36"Renminbi Zheng Zhujian Bei Quanqiu Jiena [RMB Increasingly Acknowledged by the World]," Lianhe Zaobao, July 20, 2014, http://www.zaobao.com/finance/comment/ story20140720-367956. 
grand ambitions. Therefore, it is necessary for China to further open its domestic market to the world, especially neighboring countries and other developing economies, so that the whole world can benefit from China's robust economic growth. Meanwhile, China needs to play a more active role in various global and regional financial institutions, and make bigger contributions to common development and crisis relief around the world, in order to win over more partners in promoting the reformation of the international monetary system.

Finally, China must learn to exercise political coercion in a decisive yet prudent way. As exemplified by the U.S. Dollar's ascent to world supremacy, coercion is the last and most forceful resort of an international currency. During the first five decades or so after the founding of the People's Republic in 1949, China rarely applied coercion in its engagement with the international regime, as its very limited coercive power had to be used to protect such core national interests as national security and territorial integrity. In recent years, however, China has begun to exercise coercion in international economic arenas, especially by more frequently employing retaliatory measures against the protectionist moves of other markets. For example, in the face of EU anti-dumping duties on Chinese photovoltaic products in 2013, China threatened to impose punitive duties on imports from Europe of wine and key parts used in making solar panels, and finally reached an agreement with the EU based on mutual compromise. ${ }^{37}$ Such coercive measures may very possibly be applied to guard the RMB's international status as well.

In all, as a major driving force behind the reformation of the U.S. Dollar system, the rise of the RMB will certainly bring about increasing political contention on the global stage, particularly between China and the United States. The United States may remain calm to RMB internationalization for the time being, or even encourage the RMB to play a bigger role in the international monetary system, in order to enhance the feasibility of

37Jonathan Stearns, "EU Nations Approve Pact with China on Solar-Panel Imports," Bloomberg Business, December 3, 2013, http://www.bloomberg.com/news/articles/2013-12-02/ u-nations-approve-pact-with-china-on-solar-panel-trade. 
its own monetary policy. ${ }^{38}$ Yet when it finds the RMB so widely used as to start replacing the Dollar in the global economy, the United States will certainly take measures to confine the future space of the RMB, for the Dollar supremacy is as important as its military supremacy to maintaining its leading position in the world. How China manages to reach an agreement with the United States on accommodating the continuing rise of the RMB while promoting a multi-currency international monetary system, is an arduous task for Chinese diplomacy in the years to come.

\section{Conclusion}

China's dependence on the U.S. Dollar system during the first three decades of its reform and opening up was essential to China's development into an export-oriented economy. By free-riding on the Dollar, China managed to achieve its dual strategic goals of promoting export and attracting foreign investment, laying the foundation for its rapid economic rise. Facing the increasing problems of the U.S. Dollar system, however, a more ambitious China has proactively conducted its monetary diplomacy since the outbreak of the 2008 U.S. financial crisis, and is transforming from a dependent to a reformer of the international monetary system.

In view of the myriad problems with China's domestic institutions and the heavy dependence of the world economy on the U.S. Dollar, China will encounter many challenges on its road as a systemic reformer. Whether China can develop into a great power in international monetary arenas is not only a function of China's economic growth in the future, but more importantly, depends on the continuing advancement of its political leadership as well.

\footnotetext{
${ }^{38}$ Many U.S. economists argue that the U.S. ought to support the diversification trends of the international monetary system, because a strong Dollar coupled with a huge trade deficit hinders the adjustment of the U.S.' economic policy. See, for instance, C. Fred Bergsten, "The Dollar and the Deficits: How Washington Can Prevent the Next Crisis," Foreign Affairs, Vol. 88, No. 6 (November/December 2009), pp. 23-25.
} 